\title{
Immunomodulatory Constituents from an Ascomycete, Microascus tardifaciens
}

\author{
Haruhiro FujImoto, ${ }^{*}$ Toshiyuki FujImaKı, Emi OKuYAma, and Mikio YamazAKI \\ Faculty of Pharmaceutical Sciences, Chiba University, 1-33, Yayoi-cho, Inage-ku, Chiba 263-8522, Japan. \\ Received May 13, 1999; accepted July 5, 1999
}

Fractionation guided by the immunosuppressive activity of the defatted AcOEt extract of an Ascomycete, Microascus tardifaciens, afforded eight constituents, questin (emodin 8-O-methylether) (1), rubrocristin (2), 5,7dihydroxy-4-methylphthalide (3), cladosporin (asperentin) (4), cladosporin 8-O-methylether (5), tardioxopiperazine A [cyclo-L-alanyl-5-isopentenyl-2-(1',1'-dimethylallyl)-L-tryptophan] (6), tardioxopiperazine B [cyclo-Lalanyl-7-isopentenyl-2-(1',1'-dimethylallyl)-L-tryptophan] (7), and asperflavin (8), among which 6 and 7 were new compounds. Compounds 1 and 2 showed considerably high immunosuppressive activity, 6 was moderate and, $3,4,5,7$ and 8 showed low activity.

Key words fungal metabolite; Ascomycete; Microascus tardifaciens; immunosuppressive activity; rubrocristin; tardioxopiperazine

Recently, several immunosuppressive 2-pyrones, multiforisins A-I from Gelasinospora multiforis, ${ }^{1 a, b)} \mathrm{G}$. heterospora, ${ }^{1 b)}$ and $G$. longispora, ${ }^{1 b)}$ and macrophin from Diplogelasinospora grovesii, ${ }^{1()}$ a macrocyclic sesterterpene, kobiin, and three 2-furanones, kobifuranones $\mathrm{A}-\mathrm{C}$ from $G$. $k o b i{ }^{1 d)}$ and a hexaketide, sordarial, from $G$. heterospora ${ }^{1 b}$ and $G$. longispora ${ }^{1 b}{ }^{1 b}$ have been isolated in our screening program on immunomodulatory components from fungi. Successively, it was found that the defatted AcOEt extract of an Ascomycete, Microascus tardifaciens, appreciably suppressed the proliferation (blastogenesis) of mouse splenic lymphocytes stimulated with mitogens, concanavalin A (Con A) and lipopolysaccharide (LPS). A solvent partition followed by repeated chromatographic fractionation of the extract guided by immunosuppressive activity afforded eight constituents, tentatively named MT-1 (1)-8 (8). This report deals with the structures and immunosuppressive activities of these constituents recently isolated from $M$. tardifaciens.

\section{Results and Discussion}

The AcOEt extract of $M$. tardifaciens IFM4564 ${ }^{2)}$ cultivated on sterilized rice was partitioned between $n$-hexane and water. The aqueous suspension (a defatted AcOEt extract) was further partitioned between AcOEt and water. After evaporation, $n$-hexane, AcOEt, and aqueous layers suppressed the Con A-induced proliferation of mouse splenic lymphocytes by 41,99 , and $74 \%$ at $50 \mu \mathrm{g} / \mathrm{ml}$, and by 4,64 , and $11 \%$ at $10 \mu \mathrm{g} / \mathrm{ml}$, respectively. Repeated chromatographic fractionation of the AcOEt layer guided by the immunosuppressive activity afforded eight constituents, MT$1-8(1-8)$ [yields $(\%)$ from the AcOEt layer, 1: 0.086, 2: $0.029,3: 0.19,4: 0.77,5: 0.37,6: 0.13,7: 0.13$, and 8: 0.23 ]. Among them 1 and 2 showed considerably high immunosuppressive activity, 6 showed moderate activity, and 3, 4, 5, 7, and $\mathbf{8}$ were low.

MT-1 (1), yellow fine needles, was positive to the $\mathrm{FeCl}_{3}$ reaction. The ${ }^{1} \mathrm{H}$ - and ${ }^{13} \mathrm{C}-\mathrm{NMR}$ spectral data [in dimethyl sulfoxide- $d_{6}\left(\mathrm{DMSO}-d_{6}\right)$ ], including spin-decoupling ${ }^{1} \mathrm{H}-\mathrm{NMR}$, two dimensional ${ }^{1} \mathrm{H}-{ }^{1} \mathrm{H}$ shift correlation spectroscopy (COSY), and ${ }^{1} \mathrm{H}$-detected heteronuclear correlation through multiple quantum coherence (HMQC) NMR data, suggested the presence of a methyl, a methoxyl, two pairs of meta-cou-

* To whom correspondence should be addressed. pled aromatic protons, a hydrogen-bonded hydroxyl, four aromatic quaternary carbons, three aromatic quaternary carbons bearing oxygen, and two ketone carbonyls in 1 (Table 1). These structural units were connected by the aid of ${ }^{1} \mathrm{H}$-detected heteronuclear multiple-bond correlation (HMBC) NMR data to construct a whole molecular structure (1), which was equal to the structure of questin [emodin (9) 8-Omethylether] isolated from Penicillium frequentans ${ }^{3)}$ and many other fungi. ${ }^{4)}$ MT-1 was identified with the authentic sample of questin (1) by direct comparison (Chart 1).

MT-2 (2), a fine red powder, $\mathrm{C}_{16} \mathrm{H}_{12} \mathrm{O}_{6}$, was positive to the $\mathrm{FeCl}_{3}$ reaction. The ${ }^{1} \mathrm{H}-\mathrm{NMR}$ spectrum of 2 was quite similar to that of 1 except for the additional appearance of a signal due to a hydrogen-bonded $\mathrm{OH}$ at $\delta 13.07$ (s) instead of the disappearance of that due to $\mathrm{H}-4$, as well as a change of that due to $\mathrm{H}-2$ from $\delta 7.13$ (d) to $\delta 7.26$ (s), indicating that MT-2 might be 4-hydroxyquestin (2). This was also supported by the ${ }^{13} \mathrm{C}-\mathrm{NMR}$ spectral data (Table 1). 4-Hydroxyquestin, namely, 1,4,6-trihydroxy-8-methoxy-3-methylanthraquinone, has previously been isolated from Aspergillus cristatus and named rubrocristin. ${ }^{5)}$ The UV and electron impact (EI)-MS spectral data of MT-2 were similar to those of rubrocristin (2) and the ${ }^{1} \mathrm{H}$-NMR spectral data of the 6-acetyl derivative of MT-2 was quite similar to that of rubrocristin-6-acetate (10) described in the literature (Table 1$),{ }^{5)}$ indicating that MT-2 is identical with 2 (Chart 1).

MT-4 (4), optically active pale yellow prisms, was positive to the $\mathrm{FeCl}_{3}$ reaction. The ${ }^{1} \mathrm{H}$ - and ${ }^{13} \mathrm{C}$-NMR spectral data (in DMSO- $d_{6}$ ) suggested the presence of a methyl, five aliphatic methylenes, three aliphatic methines bearing oxygen, two aromatic protons meta-coupled with each other, four aromatic quaternary carbons among which two bore oxygen, one ester carbonyl, and a hydrogen-bonded hydroxyl in 4 (Table 2). These structural units were connected on the basis of HMBC NMR data to build up a whole molecular structure (4) (without stereochemistry), which was equal to the structure of an antifungal metabolite, cladosporin (asperentin) isolated from Cladosporium cladosporioides ${ }^{6 a)}$ and Aspergillus flavus. ${ }^{6 b)}$ Comparison of the ${ }^{1} \mathrm{H}$ - and ${ }^{13} \mathrm{C}-\mathrm{NMR}$ data, melting point, specific rotation $\left([\alpha]_{\mathrm{D}}\right)$, EI-MS, UV, and circular dichroism (CD) spectral data of MT-4 with those of cladosporin described in the literature ${ }^{6 a, b)}$ showed that MT-4 is (C) 1999 Pharmaceutical Society of Japan 
Table 1. ${ }^{1} \mathrm{H}-\mathrm{NMR}$ and ${ }^{13} \mathrm{C}-\mathrm{NMR}$ Data for MT-1 (1) and MT-2 (2), and ${ }^{1} \mathrm{H}-\mathrm{NMR}$ Data for 6-Acetyl MT-2 (10) and Rubrocristin-6-acetate)

\begin{tabular}{|c|c|c|c|c|c|c|}
\hline Position & ${ }^{1} \mathrm{H}-\mathrm{NMR}$ & ${ }^{13} \mathrm{C}-\mathrm{NMR}$ & ${ }^{1} \mathrm{H}-\mathrm{NMR}{ }^{\text {in }}$ & ${ }^{6} \mathrm{C}-\mathrm{NMR}$ & $\begin{array}{c}10 \\
\text { in } \mathrm{CDCl}_{3} \\
{ }^{1} \mathrm{H}-\mathrm{NMR}\end{array}$ & $\begin{array}{l}\text { Rubrocristin-6-acetate }{ }^{5)} \\
\text { in } \mathrm{CDCl}_{3} \\
{ }^{1} \mathrm{H}-\mathrm{NMR}\end{array}$ \\
\hline 1 & & $161.59(\mathrm{~s})$ & & $155.97(\mathrm{~s})$ & & \\
\hline $\mathrm{HO}-1$ & $13.24(\mathrm{~s})$ & & $13.55(\mathrm{~s})$ & & $13.32(\mathrm{~s})^{b)}$ & $13.32(\mathrm{~s})^{c)}$ \\
\hline 2 & $7.13(\mathrm{~d}, 1.7)$ & $124.06(\mathrm{~d})$ & $7.26(s)$ & $129.35(\mathrm{~d})$ & $7.17(\mathrm{brs})$ & $7.15(\mathrm{~m})$ \\
\hline 3 & & $146.50(\mathrm{~s})$ & & $137.50(\mathrm{~s})$ & & \\
\hline $\mathrm{CH}_{3}-3$ & $2.39(3 \mathrm{H}, \mathrm{s})$ & $21.26(q)$ & $2.25(3 \mathrm{H}, \mathrm{s})$ & $15.62(q)$ & $2.35(3 \mathrm{H}, \mathrm{d}, 0.9)$ & $2.35(3 \mathrm{H}, \mathrm{d}, 1.0)$ \\
\hline 4 & 7.43 (d, 1.7$)$ & 118.99 (d) & & $155.41(\mathrm{~s})$ & & \\
\hline HO-4 & & & $13.07(\mathrm{~s})$ & & $13.22(\mathrm{~s})^{b)}$ & $13.22(\mathrm{~s})^{c)}$ \\
\hline $4 a$ & & $131.92(\mathrm{~s})^{a)}$ & & $111.59(\mathrm{~s})$ & & \\
\hline 5 & $7.21(\mathrm{~d}, 2.3)$ & $106.87(\mathrm{~d})$ & $7.29(\mathrm{~d}, 2.4)$ & $106.57(d)$ & $7.78(\mathrm{~d}, 2.3)$ & $7.78(\mathrm{~d}, 2.5)$ \\
\hline 6 & & $164.40(\mathrm{~s})$ & & $164.46(\mathrm{~s})$ & & \\
\hline $\mathrm{AcO}-6$ & & & & & $2.39(3 \mathrm{H}, \mathrm{s})$ & $2.39(3 \mathrm{H}, \mathrm{s})$ \\
\hline 7 & $6.85(\mathrm{~d}, 2.3)$ & $104.87(\mathrm{~d})$ & $6.86(\mathrm{~d}, 2.4)$ & $105.38(d)$ & $7.14(\mathrm{~d}, 2.3)$ & $7.15(\mathrm{~m})$ \\
\hline 8 & & $163.34(\mathrm{~s})$ & & $163.48(\mathrm{~s})$ & & \\
\hline $\mathrm{H}_{3} \mathrm{CO}-8$ & $3.91(3 \mathrm{H}, \mathrm{s})$ & $56.21(q)$ & $3.90(3 \mathrm{H}, \mathrm{s})$ & $56.30(q)$ & $4.06(3 \mathrm{H}, \mathrm{s})$ & $4.07(3 \mathrm{H}, \mathrm{s})$ \\
\hline $8 a$ & & $112.50(\mathrm{~s})$ & & $112.85(\mathrm{~s})$ & & \\
\hline 9 & & $186.20(\mathrm{~s})$ & & $184.79(\mathrm{~s})$ & & \\
\hline $9 a$ & & $114.27(\mathrm{~s})$ & & $111.18(\mathrm{~s})$ & & \\
\hline 10 & & $182.20(\mathrm{~s})$ & & $186.92(\mathrm{~s})$ & & \\
\hline $10 \mathrm{a}$ & & $136.69(\mathrm{~s})^{a)}$ & & $136.49(\mathrm{~s})$ & & \\
\hline
\end{tabular}

$\delta(\mathrm{ppm})$ from tetramethylsilane (TMS) as an internal standard [coupling constants $(\mathrm{Hz})$ in parentheses]. $a, b, c)$ may be interchangeable.
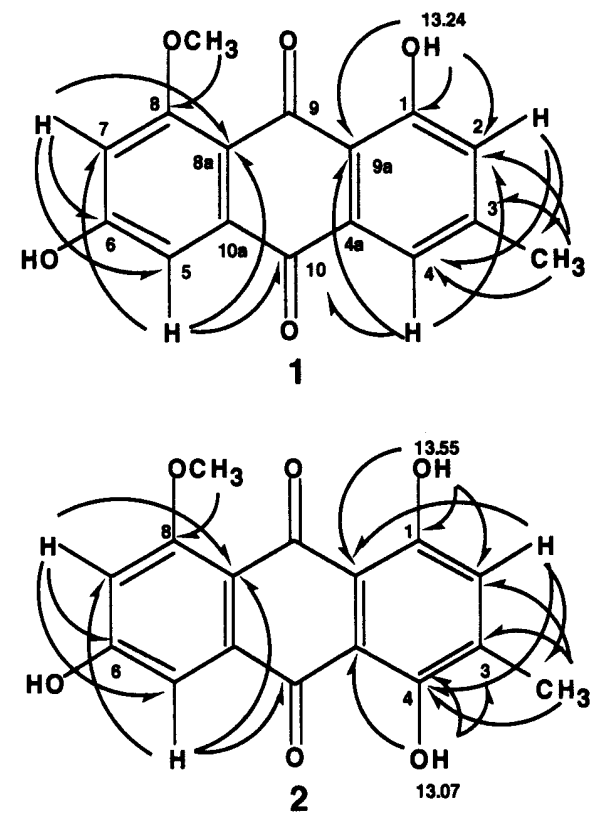

${ }^{1} \mathrm{H}-\mathrm{NMR}: \delta$ (ppm) in DMSO-d 6

$\mathrm{H} C: \mathrm{HMBC}(\mathrm{J}=8 \mathrm{~Hz})$<smiles>Cc1ccc2c(c1O)C(=O)c1c(O)ccc(O)c1C2=O</smiles><smiles></smiles>

Chart 1

identical with cladosporin (4), including stereochemistry (Chart 2). The absolute configurations at positions 3,10 , and 14 in 4 were already determined to be $(R),(R)$, and $(S)$, respectively. ${ }^{6 c)}$

MT-5 (5), an optically active pale yellow powder, was negative to the $\mathrm{FeCl}_{3}$ reaction. The ${ }^{1} \mathrm{H}$ - and ${ }^{13} \mathrm{C}$-NMR spectra of 5 were quite similar to those of 4 , except for the additional appearance of signals due to a methoxyl [ $\delta_{\mathrm{H}} 3.74(3 \mathrm{H}, \mathrm{s}), \delta_{\mathrm{C}}$ 55.54 (q)], instead of the disappearance of that due to a hydrogen-bonded OH-8 (Table 2), suggesting that 5 might be 8$O$-methylether of 4 . On treatment with trimethylsilyldiazomethane, 4 afforded dimethylether (11), which was also obtained from 5 with the same treatment. Accordingly, MT-5 was deduced to be identical with cladosporin (asperentin) 8$O$-methylether (5), which was already isolated from $A s$ pergillus flavus. ${ }^{6)}$ It has been found that the signals of $\mathrm{H}-3$ and $\mathrm{C}-3$ in the ${ }^{1} \mathrm{H}$ - and ${ }^{13} \mathrm{C}$-NMR spectra are present at $\delta_{\mathrm{H}}$ 4.61 and $\delta_{\mathrm{C}} 76.18$, and the signs of $[\alpha]_{\mathrm{D}}$ and $\Delta \varepsilon$ at $c a .300$ $\mathrm{nm}$ in the CD spectrum are negative in the case of 4 , while the corresponding signals are present at $\delta_{\mathrm{H}} 4.35$ and $\delta_{\mathrm{C}}$ 73.82 and the corresponding signs are positive in the case of 5 (see Table 2 and Experimental). These differences between the ${ }^{1} \mathrm{H}$ - and ${ }^{13} \mathrm{C}$-NMR spectra, $[\alpha]_{\mathrm{D}}$, and CD spectrum of 4 and those of 5 may be due to the difference between the con- 
Table. $2{ }^{1} \mathrm{H}-\mathrm{NMR}$ and ${ }^{13} \mathrm{C}-\mathrm{NMR}$ Data for MT-4 (4), Cladosporin, MT-5 (5), and Cladosporin 8-O-Methylether

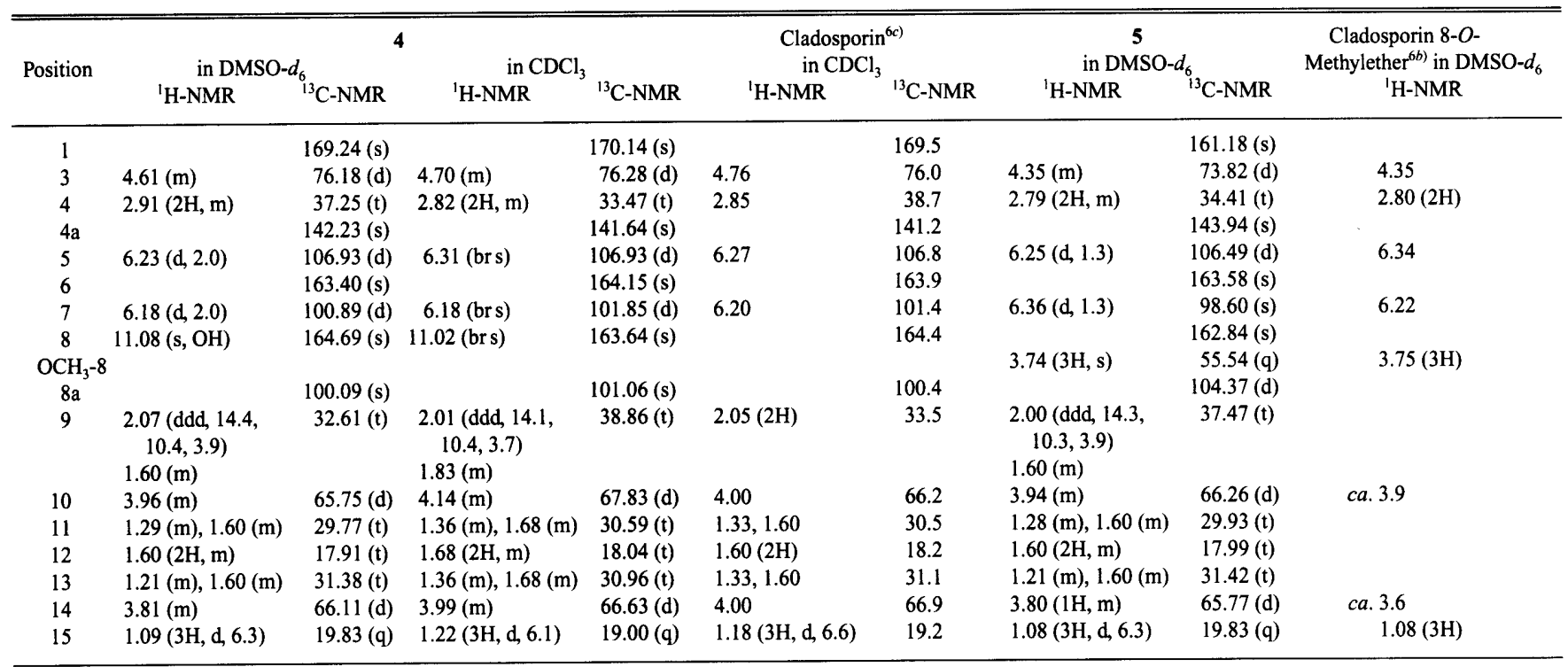

$\delta(\mathrm{ppm})$ from TMS as an internal standard [coupling constants $(\mathrm{Hz})$ in parentheses].

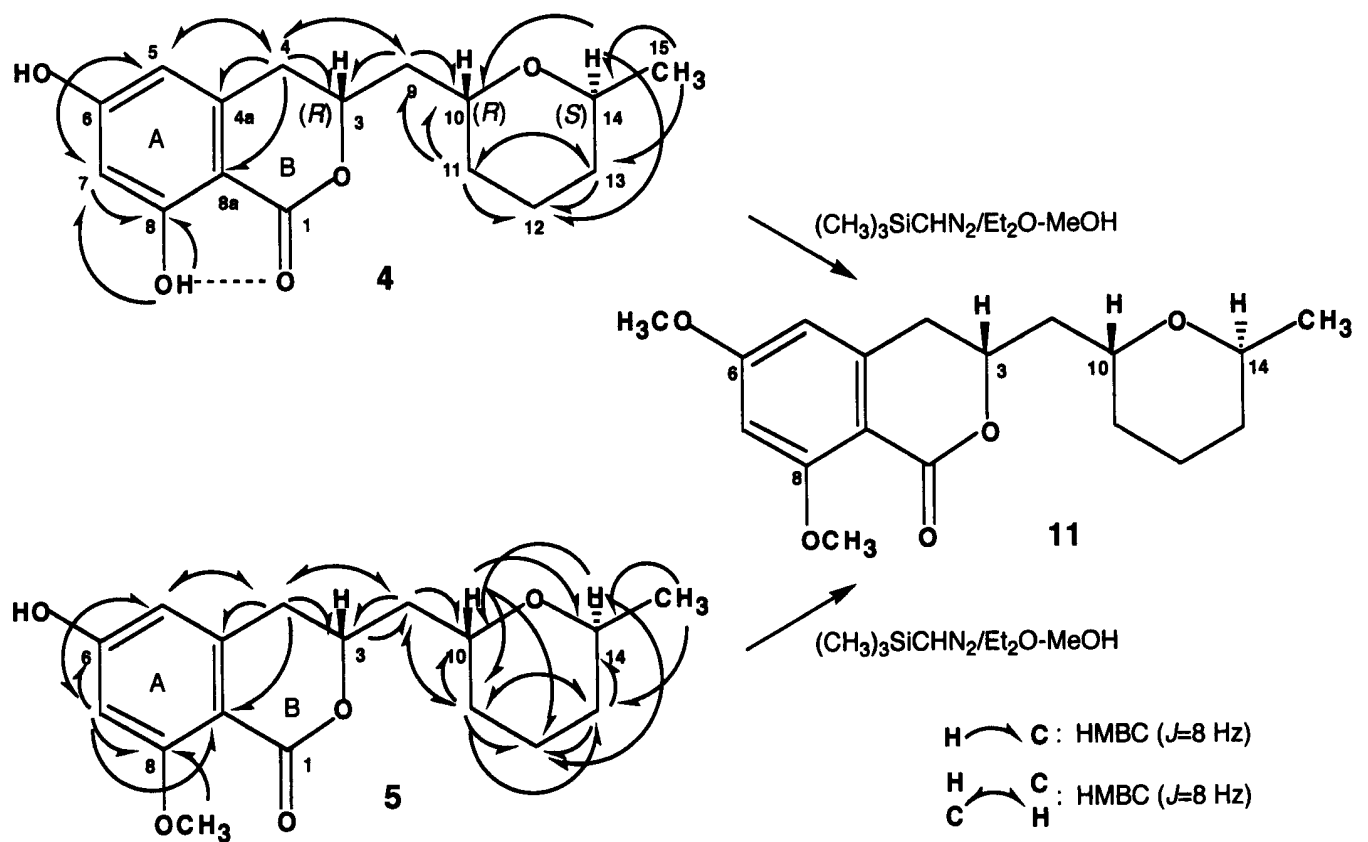

Chart 2

formation of the B ring strained by the presence of a hydrogen bond between $\mathrm{HO}-8$ and $\mathrm{CO}-1$ in 4 and that unstrained by the absence of such a hydrogen bond in $\mathbf{5}$, as shown in Chart 2.

MT-6 (6), an optically active pale yellow powder, $\mathrm{C}_{24} \mathrm{H}_{31} \mathrm{~N}_{3} \mathrm{O}_{2}$, was positive to the Van Urk reaction, ${ }^{7)}$ suggesting the presence of an indole skeleton in 6 . The ${ }^{1} \mathrm{H}$ - and ${ }^{13} \mathrm{C}$ NMR spectral data of 6 (in DMSO- $d_{6}$ ) showed that 6 is composed of seven partial structures, $a$ ) 2,3,5-trisubstituted indole $\left(\mathrm{C}_{8} \mathrm{H}_{4} \mathrm{~N}\right)$, b) isopentenyl $\left[\left(\mathrm{CH}_{3}\right) 2 \mathrm{C}=\mathrm{CHCH}_{2}-\right]$, c) 1,1dimethylallyl $\left[\mathrm{CH}_{2}=\mathrm{CHC}\left(\mathrm{CH}_{3}\right)_{2}-\right]$, d) $\mathrm{CH}_{3} \mathrm{CH}(\mathrm{NH})-$, e) $\left.-\mathrm{CH}_{2} \mathrm{CH}(\mathrm{NH})-, \boldsymbol{f}\right)>\mathrm{CO}$, and $g$ ) $>\mathrm{CO}$. Then, the partial structures $d-g$ were connected with the aid of HMBC NMR data to obtain an expanded partial structure, $\boldsymbol{h}$ ) 3-methyl-6methylene-2,5-dioxopiperazine. Finally, the four partial structures $\boldsymbol{a}, \boldsymbol{b}, \boldsymbol{c}$, and $\boldsymbol{h}$ were united on the basis of detailed
HMBC NMR data to construct a whole molecular structure (6) [ cyclo-alanyl-5-isopentenyl-2-(1',1'-dimethylallyl)tryptophan] (without stereochemistry). The constructed structure (6) was similar to the structure of echinulin [cyclo-L-alanyl5,7-diisopentenyl-2-(1',1'-dimethylallyl)-L-tryptophan] (12), a 2,5-dioxopiperazine isolated from Aspergillus echinulatus and other Aspergillus glaucus group fungi. ${ }^{8 a}$ This was also supported by the ${ }^{1} \mathrm{H}-\mathrm{NMR}$ spectral data of 12 described in the literature. ${ }^{8 b}$ ) It is already known that 12 gave a similar molecular rotation $([\phi])$ in the optical rotatory dispersion (ORD) spectrum to those of cyclo-L-alanyl-2-(1',1'-dimethylallyl)-L-tryptophan (13). ${ }^{8 c)}$ MT-6 afforded a similar $[\phi]([\phi]$ (nm): $\left.-19000^{\circ}(235),+18400^{\circ}(212)\right)$ in the ORD spectrum to those of $12\left(-15500^{\circ}(238),+19950^{\circ}(216)\right)$ and 13 $\left(-27200^{\circ}(230),+46250^{\circ}(214)\right)$, as described in the literature, ${ }^{8 c)}$ indicating that the stereostructure of MT- 6 was de- 
Table 3. ${ }^{1} \mathrm{H}-\mathrm{NMR}$ and ${ }^{13} \mathrm{C}-\mathrm{NMR}$ Data for MT-6 (6), MT-7 (7), and Echinulin

\begin{tabular}{|c|c|c|c|c|c|}
\hline \multirow{2}{*}{ Position } & \multicolumn{2}{|c|}{$6^{a)}$} & \multicolumn{2}{|c|}{$7^{a)}$} & \multirow{2}{*}{$\begin{array}{c}\text { Echinulin }{ }^{b, 8 b)} \\
{ }^{1} \mathrm{H} \text {-NMR }\end{array}$} \\
\hline & ${ }^{1} \mathrm{H}-\mathrm{NMR}$ & ${ }^{13} \mathrm{C}-\mathrm{NMR}$ & ${ }^{1} \mathrm{H}-\mathrm{NMR}$ & ${ }^{13} \mathrm{C}-\mathrm{NMR}$ & \\
\hline NH-1 & $10.42(\mathrm{~s})$ & & & $9.80(\mathrm{~s})$ & \\
\hline 2 & & $141.46(\mathrm{~s})$ & & $141.34(\mathrm{~s})$ & \\
\hline 3 & & $104.32(\mathrm{~s})$ & . & $105.42(\mathrm{~s})$ & \\
\hline $3 a$ & & $129.16(\mathrm{~s})$ & & $128.93(\mathrm{~s})$ & \\
\hline 4 & $7.19(\mathrm{~s})$ & $116.92(d)$ & $7.27(\mathrm{~d}, 7.8)$ & $115.58(\mathrm{~d})$ & 6.78 or 7.12 \\
\hline 5 & & $131.08(\mathrm{~s})$ & 6.89 (dd, $7.8,7.0)$ & $118.81(\mathrm{~d})$ & \\
\hline 6 & $6.82(\mathrm{~d}, 8.3)$ & $121.31(\mathrm{~d})$ & $6.81(\mathrm{~d}, 7.0)$ & 119.98 (d) & 6.78 or 7.12 \\
\hline 7 & $7.21(\mathrm{~d}, 8.3)$ & $110.70(d)$ & & $123.75(\mathrm{~s})$ & \\
\hline $7 a$ & & $133.39(\mathrm{~s})$ & & $133.59(\mathrm{~s})$ & \\
\hline \multirow[t]{2}{*}{8} & $3.00(\mathrm{dd}, 14.5,9.4)$ & $31.12(\mathrm{t})$ & $3.07(\mathrm{dd}, 14.5,9.4)$ & $31.19(t)$ & $3.12-3.79$ \\
\hline & $3.30(\mathrm{~m})$ & & $3.35(\mathrm{~m})$ & & \\
\hline 9 & $3.93(\mathrm{~m})$ & $55.58(\mathrm{~d})$ & $3.94(\mathrm{~m})$ & $55.64(d)$ & $3.96-4.50$ \\
\hline NH-10 & $7.44(d, 3.0)$ & & $7.48(\mathrm{~d}, 2.7)$ & & 8.04 \\
\hline 11 & & $167.84(s)$ & & $167.90(\mathrm{~s})$ & \\
\hline 12 & $3.79(\mathrm{~m})$ & $50.30(\mathrm{~d})$ & $3.80(\mathrm{~m})$ & $50.29(\mathrm{~d})$ & $3.96-4.50$ \\
\hline $\mathrm{CH}_{3}-12$ & $1.29(3 \mathrm{H}, \mathrm{d}, 7.1)$ & $20.72(q)$ & $1.27(3 \mathrm{H}, \mathrm{d}, 7.1)$ & $20.69(q)$ & 1.51 \\
\hline NH-13 & $8.17(\mathrm{~d}, 2.7)$ & & $8.16(\mathrm{~d}, 2.4)$ & & 8.04 \\
\hline 14 & & $167.37(\mathrm{~s})$ & & $167.31(t)$ & \\
\hline 15 & & $39.92(\mathrm{~s})$ & & $39.92(\mathrm{~s})$ & \\
\hline 16 & $6.14(\mathrm{dd}, 17.1,10.2)$ & $146.54(d)$ & $6.24(\mathrm{dd}, 17.5,10.6)$ & $146.73(d)$ & $5.77-6.50$ \\
\hline \multirow[t]{2}{*}{17} & $5.01(\mathrm{dd}, 10.2,1.0)$ & $110.98(t)$ & $5.05(\mathrm{dd}, 10.6,1.2)$ & $111.02(t)$ & $4.87-5.29$ \\
\hline & 5.04 (dd, 17.1, 1.0) & & $5.09(\mathrm{dd}, 17.5,1.2)$ & & \\
\hline 18 & $1.45(3 \mathrm{H}, \mathrm{s})$ & $27.97(q)$ & $1.52(3 \mathrm{H}, \mathrm{s})$ & $27.96(q)$ & 1.51 \\
\hline 19 & $1.46(3 \mathrm{H}, \mathrm{s})$ & $27.97(q)$ & $1.53(3 \mathrm{H}, \mathrm{s})$ & $28.00(q)$ & 1.51 \\
\hline 20 & $3.30(2 \mathrm{H}, \mathrm{m})$ & $34.17(\mathrm{t})$ & $3.60(2 \mathrm{H}, \mathrm{d}, 7.1)$ & $28.89(\mathrm{t})$ & $3.12-3.79$ \\
\hline 21 & $5.31(t, 7.3)$ & $124.84(d)$ & $5.40(\mathrm{~m})$ & $122.62(d)$ & $4.87-5.29$ \\
\hline 22 & & $130.34(s)$ & & $131.64(\mathrm{~s})$ & \\
\hline 23 & $1.68(3 \mathrm{H}, \mathrm{s})$ & $25.53(q)$ & $1.74(3 \mathrm{H}, \mathrm{s})$ & $25.56(q)$ & 1.73 \\
\hline 24 & $1.69(3 \mathrm{H}, \mathrm{s})$ & $17.67(q)$ & $1.74(3 \mathrm{H}, \mathrm{s})$ & $17.72(q)$ & 1.73 \\
\hline 25 & & & & & $3.12-3.79$ \\
\hline 26 & & & & & $4.87-5.29$ \\
\hline \multicolumn{6}{|l|}{27} \\
\hline 28 & & & & & 1.73 \\
\hline 29 & & & & & 1.73 \\
\hline
\end{tabular}

$\delta(\mathrm{ppm})$ from TMS as an internal standard [coupling constants $(\mathrm{Hz})$ in parentheses]. $a$ ) in DMSO- $\left.d_{6}, b\right)$ in $\mathrm{CDCl}_{3}$.

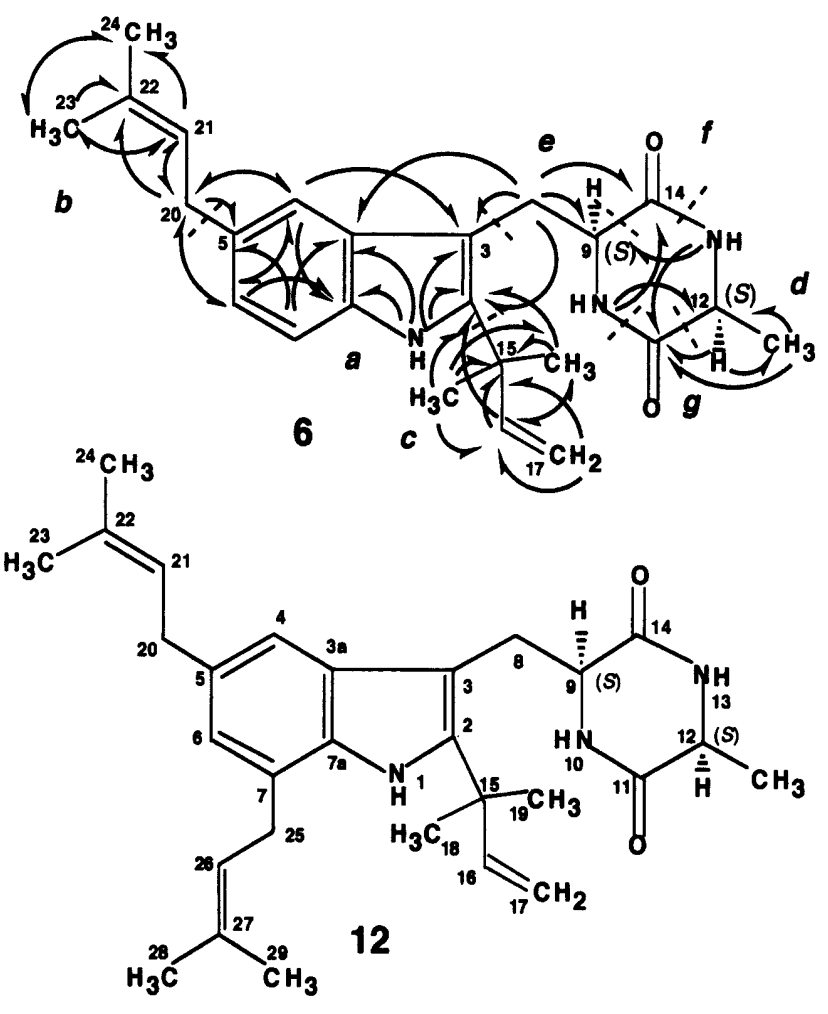<smiles>C=CC(C)(C)c1[nH]c2ccccc2c1C[C@H]1NC(=O)[C@H](C)NC1=O</smiles>

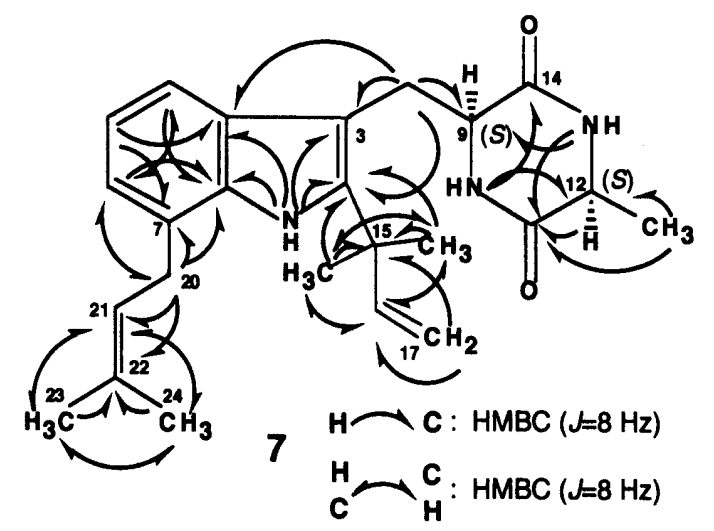

Chart 3 
Table 4. ${ }^{1} \mathrm{H}-\mathrm{NMR}$ and ${ }^{13} \mathrm{C}-\mathrm{NMR}$ Data for MT-3 (3), MT-8 (8), 5,7-Dihydroxy-4-methylphthalide, and Asperflavin

\begin{tabular}{|c|c|c|c|c|c|c|c|}
\hline \multirow[b]{2}{*}{ Position } & \multicolumn{2}{|c|}{3} & \multirow{2}{*}{$\begin{array}{c}\text { 5,7-Dihydroxy-4- } \\
\text { methylphthalide }^{9} \\
\text { 'H-NMR }\end{array}$} & \multirow[b]{2}{*}{ Position } & \multicolumn{2}{|c|}{8} & \multirow{2}{*}{$\begin{array}{c}\text { Asperflavin9) } \\
{ }^{1} \text { H-NMR }\end{array}$} \\
\hline & ${ }^{1} \mathrm{H}-\mathrm{NMR}$ & ${ }^{13} \mathrm{C}-\mathrm{NMR}$ & & & ${ }^{1} \mathrm{H}-\mathrm{NMR}$ & ${ }^{13} \mathrm{C}-\mathrm{NMR}$ & \\
\hline 1 & & $173.36(\mathrm{~s})$ & & 1 & & $204.02(s)$ & \\
\hline 3 & $5.17(2 \mathrm{H}, \mathrm{s})$ & $70.16(s)$ & $5.2(2 \mathrm{H}, \mathrm{s})$ & 2 & $2.71,2.79$ & $52.49(\mathrm{t})$ & $2.78(2 \mathrm{H})$ \\
\hline $3 a$ & & $150.16(\mathrm{~s})$ & & 3 & (each d, 17.1) & $71.24(\mathrm{~s})$ & \\
\hline 4 & & $111.09(\mathrm{~s})$ & & $\mathrm{CH}_{3}-3$ & $1.34(3 \mathrm{H}, \mathrm{s})$ & $28.90(q)$ & $1.36(3 \mathrm{H})$ \\
\hline $\mathrm{CH}_{3}-4$ & $2.01(3 \mathrm{H}, \mathrm{s})$ & $10.27(q)$ & $2.05(3 \mathrm{H}, \mathrm{s})$ & 4 & $2.97(2 \mathrm{H}, \mathrm{br} \mathrm{s})$ & $44.10(t)$ & $3.00(2 \mathrm{H})$ \\
\hline 5 & & $164.29(\mathrm{~s})$ & & $4 a$ & & $138.36(\mathrm{~s})$ & \\
\hline 6 & $6.34(1 \mathrm{H}, \mathrm{s})$ & $103.00(d)$ & $6.38(1 \mathrm{H}, \mathrm{s})$ & 5 & $6.51(\mathrm{~d}, 2.2)$ & $103.46(d)$ & 6.50 \\
\hline 7 & & $157.52(\mathrm{~s})$ & & 6 & & $161.98(s)$ & \\
\hline \multirow[t]{8}{*}{$7 a$} & & $103.60(\mathrm{~s})$ & & 7 & $6.43(\mathrm{~d}, 2.2)$ & 98.88 (d) & 6.43 \\
\hline & & & & 8 & & $162.86(\mathrm{~s})$ & \\
\hline & & & & $\mathrm{CH}_{3} \mathrm{O}-8$ & $3.90(3 \mathrm{H}, \mathrm{s})$ & $56.29(q)$ & $3.92(3 \mathrm{H})$ \\
\hline & & & & $8 a$ & & $110.33(\mathrm{~s})$ & \\
\hline & & & & 9 & & $166.48(\mathrm{~s})$ & \\
\hline & & & & $9 a$ & & $110.25(\mathrm{~s})$ & \\
\hline & & & & 10 & $6.75(\mathrm{~s})$ & $117.68(\mathrm{~s})$ & 6.75 \\
\hline & & & & $10 \mathrm{a}$ & & $143.69(\mathrm{~s})$ & \\
\hline
\end{tabular}

$\delta(\mathrm{ppm})$ from TMS as an internal standard in $\mathrm{CD}_{3} \mathrm{OD}$ [coupling constants $(\mathrm{Hz})$ in parentheses].

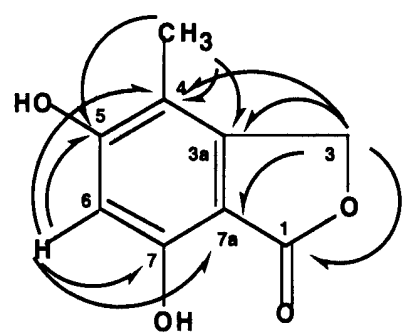

3

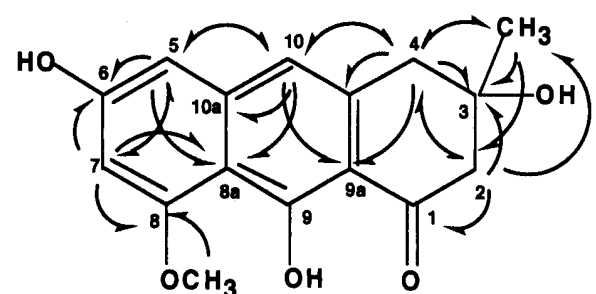

8

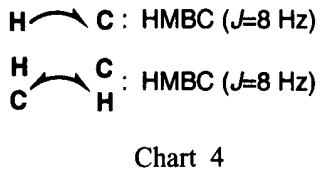

duced to be $c y c l o$-L-alanyl-5-isopentenyl-2-( $\left(1^{\prime}, 1^{\prime}\right.$-dimethylallyl)-L-tryptophan (6), as shown in Chart 3.

MT-7 (7), an optically active pale yellow powder, $\mathrm{C}_{24} \mathrm{H}_{31} \mathrm{~N}_{3} \mathrm{O}_{2}$, was positive to the Van Urk reaction. The ${ }^{1} \mathrm{H}-$ and ${ }^{13} \mathrm{C}$-NMR spectral data of 7 indicated that signals due to the isopentenyl group at position 5 and the aromatic $\mathrm{CH}$ at position 7 in 6 were substituted with those of an aromatic $\mathrm{CH}$ and an isopentenyl group in 7, respectively (Table 3), suggesting that MT-7 might be cyclo-alanyl-7-isopentenyl-2$\left(1^{\prime}, 1^{\prime}\right.$-dimethylallyl)tryptophan (7). The fact that MT-7 gave a similar $[\phi]\left([\phi](\mathrm{nm}):-28200^{\circ}(232),+27500^{\circ}(215)\right)$ to that of 6 indicated that the stereostructure of 7 was deduced to be cyclo-L-alanyl-7-isopentenyl-2-(1',1'-dimethylallyl)-Ltryptophan (7) (Chart 3). To our knowledge, this is the first time that cyclo-L-alanyl-5-isopentenyl-2- $\left(1^{\prime}, 1^{\prime}\right.$-dimethylallyl)-L-tryptophan (6) and cyclo-L-alanyl-7-isopentenyl-2$\left(1^{\prime}, 1^{\prime}\right.$-dimethylallyl)-L-tryptophan (7) have been isolated from a natural source. We propose to call 6 and 7 tardioxopiperazines A and B, respectively.

MT-3 (3), a white powder, was positive to the $\mathrm{FeCl}_{3}$ reaction. The ${ }^{1} \mathrm{H}$ - and ${ }^{13} \mathrm{C}-\mathrm{NMR}$ data suggested the presence of a methyl, an aliphatic methylene bearing oxygen, an aromatic $\mathrm{CH}$, five aromatic quaternary carbons, and an ester carbonyl. These structural units were united by the aid of HMBC NMR data to construct a whole molecular structure (3), being compatible with the molecular ion $m / z 180$ in the EI-MS spectrum. The whole molecular structure (3) was equal to the structure of 5,7-dihydroxy-4-methylphthalide isolated from Aspergillus flavus. ${ }^{9}$ Comparison of the ${ }^{1} \mathrm{H}-\mathrm{NMR}$ data, melting point, and UV spectrum of MT-3 with those of 5,7-dihydroxy-4-methylphthalide described in the literature ${ }^{9}$ ) showed that MT-3 was deduced to be identical with 5,7-dihydroxy-4methylphthalide (3) (Chart 4).

MT-8 (8) was optically active and positive to the $\mathrm{FeCl}_{3}$ reaction. The ${ }^{1} \mathrm{H}$ - and ${ }^{13} \mathrm{C}-\mathrm{NMR}$ data showed the presence of a tert-methyl, a methoxyl, two aliphatic methylenes, three aromatic protons among which two were meta-coupled with each other, an aliphatic quaternary carbon bearing oxygen, seven aromatic quaternary carbons among which three bore oxygen, and a ketone carbonyl in 8. A whole molecular structure (8) was constructed for MT-8 from these structural units on the basis of HMBC NMR data. The whole molecular structure (8), supported by the molecular ion $\mathrm{m} / \mathrm{z} 288$ in the EI-MS spectrum, was equal to the structure of asperflavin isolated together with 3 from Aspergillus flavus. ${ }^{9)}$ However, the appearance and specific rotation of MT- 8 (greenish amorphous, $+89^{\circ}$ ) were considerably different from those of asperflavin described in the literature (citrine prism, $\left.+4^{\circ}\right),{ }^{9)}$ 
Table 5. Immunosuppressive Effects of MT-1 (1)-MT-8 (8), MT-4 Dimethylether (11), and Some Related Compounds on the Con A-Induced and LPS-Induced Proliferation of Mouse Splenic Lymphocytes

\begin{tabular}{ccc}
\hline \multirow{2}{*}{ Compound } & \multicolumn{2}{c}{$\mathrm{IC}_{50}(\mu \mathrm{g} / \mathrm{ml})$} \\
& Con A-induced & LPS-induced \\
\hline $\mathbf{1}$ & 0.3 & 0.3 \\
$\mathbf{2}$ & 0.8 & 0.1 \\
$\mathbf{3}$ & 17 & 3.0 \\
$\mathbf{4}$ & 13 & 7.5 \\
$\mathbf{6}$ & 2.3 & 13 \\
$\mathbf{7}$ & 4.5 & 0.7 \\
$\mathbf{8}$ & $>25$ & 15 \\
$\mathbf{1 1}$ & 16 & 3.6 \\
Emodin (9) & 23 & 12 \\
Azathioprine & 0.2 & 0.2 \\
Cyclosporin A & 2.7 & 2.7 \\
& 0.04 & 0.07 \\
\hline
\end{tabular}

suggesting that MT-8 (8) may be an optically active state of partially racemized asperflavin.

The immunosuppressive activities ( $\mathrm{IC}_{50}$ values) of $\mathbf{1 - 9}$ and 11 were calculated against Con A- (T-cells) and LPS-induced (B-cells) proliferation of mouse splenic lymphocytes, as shown in Table 5. Two anthraquinones, 1 and 2, which were isolated as main immunosuppressive features from $M$. tardifaciens, considerably suppressed the proliferation of both T- and B-cells, as well as emodin (9). The immunosuppressive activity of 9 has already been demonstrated on human mononuclear cells. ${ }^{10)}$ To our knowledge, this is the first time that 1 and its 4-hydroxy derivative 2 , and 4 and its 8-O-methylether (5) have been isolated as immunosuppressive features from a natural source. Tardioxopiperazine A [cyclo-L-alanyl-5-isopentenyl-2-(1', $1^{\prime}$-dimethylallyl)-L-tryptophan] (6) moderately suppressed the proliferation of both T- and B-cells, but tardioxopiperazine B [cyclo-L-alanyl-7isopentenyl-2-(1',1'-dimethylallyl)-L-tryptophan] (7) suppressed them only slightly. The immunosuppressive activities of 3-5, 8, and 11 were low in comparison with the immunosuppressive activities of two known immunosuppressants, cyclosporin $\mathrm{A}\left(\mathrm{IC}_{50}\right.$ against Con A- and LPS-induced proliferations: 0.04 and $0.07 \mu \mathrm{g} / \mathrm{ml}$ ) and azathioprine (2.7 and $2.7 \mu \mathrm{g} / \mathrm{ml})$.

\section{Experimental}

The general procedures for chemical experiments and other experimental conditions, including those for the evaluation of suppressive activity $\left(\mathrm{IC}_{50}\right.$ values) of samples against the proliferation of mouse splenic lymphocytes stimulated with Con A and LPS, were the same as those described in our previous report (this method is based on the incorporation ratio of exogenous $\left[{ }^{3} \mathrm{H}\right]$ thymidine into lymphocytes or the formation ratio of formazan from exogenous 3-(4,5-dimethyl-2-thiazolyl)-2,5-diphenyl-2 $\mathrm{H}$-tetrazolium bromide (MTT) in lymphocytes). ${ }^{1 b)}$ Chemical shifts are expressed in $\delta$ $(\mathrm{ppm})$ values from tetramethylsilane (TMS) as an internal standard.

Isolation of MT-1(1)-8(8) from $M$. tardifaciens $M$. tardifaciens IFM4564 ${ }^{2)}$ was cultivated on sterilized rice $(200 \mathrm{~g} /$ flask $\times 300)$ at $25^{\circ} \mathrm{C}$ for $27 \mathrm{~d}$. The brown colored moldy rice was extracted with AcOEt (60.01) with shaking at room temperature for $6 \mathrm{~h}$ two times to give an AcOEt solution (120.01), which gave, after evaporation in vacuo, an AcOEt extract (37.8 g). The AcOEt extract was partitioned with $n$-hexane- $\mathrm{H}_{2} \mathrm{O}(1: 1, \mathrm{v} / \mathrm{v})(2.01)$ into an $n$-hexane layer (after evaporation in vacuo, $29.1 \mathrm{~g}$ ) and an aqueous suspension, which was then partitioned with AcOEt (1.01) into an AcOEt layer $(7.0 \mathrm{~g})$ and an aqueous layer $(0.14 \mathrm{~g})$. The $n$-hexane, AcOEt, and aqueous layers suppressed the Con A-induced proliferation of mouse splenic lymphocytes by 41,99 , and $74 \%$ at $50 \mu \mathrm{g} / \mathrm{ml}$, and by $4,64,11 \%$ at 10 $\mu \mathrm{g} / \mathrm{ml}$, respectively. The AcOEt layer was subjected to chromatography on a silica gel column with $n$-hexane-acetone $(4: 1),(2: 1),(1: 1)$, and acetone to give four fractions: I $(2.9 \mathrm{~g})$, II $(0.93 \mathrm{~g})$, III $(2.0 \mathrm{~g})$, and IV $(1.1 \mathrm{~g})$. Fractions I, II, III, and IV suppressed the Con A-induced proliferation of the lymphocytes by $28,72,64$, and $49 \%$ at $10 \mu \mathrm{g} / \mathrm{ml}$, respectively. Fraction II was further chromatographed on a silica gel column with $\mathrm{C}_{6} \mathrm{H}_{6}-\mathrm{AcOEt}$ and on a Sephadex LH-20 (Pharmacia) column with $\mathrm{MeOH}$ to give three fractions, IIa-IIc. Fraction III was also further chromatographed in the similar way to give four fractions, IIIa-IIId. A mixture of fractions IIb and IIIc $(67 \mathrm{mg})$ was then chromatographed on a silica gel column with $\mathrm{CHCl}_{3}-\mathrm{MeOH}$ and on an octadecyl silica gel (ODS) column with $\mathrm{CH}_{3} \mathrm{CN}-\mathrm{H}_{2} \mathrm{O}$ to afford 1 $(6 \mathrm{mg})$ and $2(2 \mathrm{mg})$. Fraction Ila $(276 \mathrm{mg})$ was also chromatographed on a silica gel column with $\mathrm{CHCl}_{3}-\mathrm{MeOH}$ two times, on a Sephadex LH-20 column with $\mathrm{MeOH}$, and successively on a high performance liquid chromatographic (HPLC) ODS column with $\mathrm{CH}_{3} \mathrm{CN}-\mathrm{H}_{2} \mathrm{O}(1: 1)$ at a flow rate of $8.0 \mathrm{ml} / \mathrm{min}$ to afford $4(54 \mathrm{mg})$ and $3(13 \mathrm{mg})$. Fraction IIIb $(960 \mathrm{mg})$ was chromatographed on an ODS column with $\mathrm{MeOH}-\mathrm{H}_{2} \mathrm{O}$ to give three fractions, IVa-IVc. Fraction IVb $(91 \mathrm{mg})$ was chromatographed on preparative TLC plates with $n$-hexane-AcOEt $(1: 5)$ and on an HPLC ODS column with $\mathrm{CH}_{3} \mathrm{CN}-\mathrm{H}_{2} \mathrm{O}(3: 7)$ at a flow rate of $8.0 \mathrm{ml} / \mathrm{min}$ to afford $5(14 \mathrm{mg})$ and 8 $(16 \mathrm{mg})$. Fraction IVc $(296 \mathrm{mg})$ was further chromatographed on a silica gel column with $\mathrm{CHCl}_{3}-\mathrm{MeOH}$, on an ODS column with $\mathrm{CH}_{3} \mathrm{CN}-\mathrm{H}_{2} \mathrm{O}$, and successively on an HPLC ODS column with $\mathrm{CH}_{3} \mathrm{CN}-\mathrm{H}_{2} \mathrm{O}(1: 1)$ to give 6 $(9 \mathrm{mg}), 7(9 \mathrm{mg})$, and $5(12 \mathrm{mg})$.

MT-1 (1) (Questin): Fine yellow needles from EtOH, mp 297-299 ${ }^{\circ} \mathrm{C}$ (lit. ${ }^{3)}$ bright-yellow needles, $\mathrm{mp} 301-303^{\circ} \mathrm{C}$ ). EI-MS $m / z$ (\%): 284 (65, $\left.\mathrm{M}^{+}\right), 267(15), 213(28), 198(25), 182(36), 77(100)$. IR $v_{\max }^{\mathrm{KBr}} \mathrm{cm}^{-1}: 3262$ $(\mathrm{O}-\mathrm{H}), 1680,1631(\mathrm{C}=\mathrm{O}), 1592,1473(\mathrm{C}=\mathrm{C}), 1437,1352,1270,1218$ $(\mathrm{C}-\mathrm{O})$. UV $\lambda_{\max }^{\mathrm{EtOH}} \mathrm{nm}(\log \varepsilon): 224$ (4.60), $248(4.13), 286(4.41), 425$ (3.99). This compound was identical with an authentic sample of questin (1) in terms of mixed mp, ${ }^{1} \mathrm{H}-\mathrm{NMR}$ spectra, and TLC behavior [Kieselgel $60 \mathrm{~F}_{254} \mathrm{~S}$ (Merck), $n$-hexane-acetone (1:1); $\mathrm{RP} 18 \mathrm{~F}_{254} \mathrm{~S}$ (Merck), $\mathrm{CH}_{3} \mathrm{CN}-\mathrm{H}_{2} \mathrm{O}$ $(3: 1)]$

MT-2 (2) (Rubrocristin): Fine red powder, $\mathrm{mp} 280-282^{\circ} \mathrm{C}$. EI-MS $\mathrm{m} / \mathrm{z}$ (\%): $300\left(100, \mathrm{M}^{+}\right), 282(28), 253(36), 213(30), 197(31), 183$ (38) [lit. ${ }^{5)}$ $300\left(100, \mathrm{M}^{+}\right), 282(55), 254(25), 217$ (15)], high-resolution EI-MS (HREI-MS) $m / z: 300.0642\left(\mathrm{C}_{16} \mathrm{H}_{12} \mathrm{O}_{6}\right.$ requires 300.0634$)$. UV $\lambda_{\max }^{\mathrm{EtOH}} \mathrm{nm}(\log \varepsilon)$ : 231 (5.01), 253 (4.55), 280 (4.77), 306 (sh, 4.50), 481 (4.51), 495 (sh, 4.49), 515 (sh, 4.35), 530 (4.19) [lit." 230 (4.49), 254 (4.08), 280 (4.25), 300 (sh, 4.06), 480 (4.00), 495 (3.99), 512 (3.87), 528 (3.74)].

MT-3 (3) (5,7-Dihydroxy-4-methylphthalide): Fine white powder, mp $203-205^{\circ} \mathrm{C}$ (lit. ${ }^{9)} 200-203^{\circ} \mathrm{C}$ ). EI-MS $m / z(\%): 180\left(55, \mathrm{M}^{+}\right), 151(100)$, 77 (30), 69 (76). UV $\lambda_{\max }^{\mathrm{MeOH}} \mathrm{nm}(\log \varepsilon): 216(4.41), 259$ (4.05), 297 (3.68) (lit. ${ }^{9)} 227(4.20), 260$ (3.97), 297 (3.61)).

MT-4 (4) [Cladosporin (Asperentin)]: Pale yellow prism, mp 191.5$192^{\circ} \mathrm{C}\left(\right.$ lit. $\left.^{6 a)} 188.5-189^{\circ} \mathrm{C}\right),[\alpha]_{\mathrm{D}}^{22}-23.3^{\circ}(c=0.1, \mathrm{EtOH})\left[{ }^{\circ}{ }^{6}{ }^{6 a)}-24.8^{\circ}\right.$ $\left(c=0.96\right.$, EtOH)]. EI-MS $m / z$ (\%): $292\left(13, \mathrm{M}^{+}\right), 194(14), 179(56), 151$ (100). UV $\lambda_{\max }^{\mathrm{MeOH}} \mathrm{nm}(\log \varepsilon): 216(4.31), 230(\mathrm{sh}, 4.03), 268(4.10), 301$ (3.73) [lit. ${ }^{6 a)} 217$ (4.32), 230 (infl, 4.08), 270 (4.11), 303 (3.78)]. CD (1.69 mM, MeOH) $\Delta \varepsilon(\mathrm{nm}):-0.70(301),+2.40(270),-0.42(249),+2.47$ (235) [lit. $\left.{ }^{6)}-0.86(302),+2.45(268),-0.58(247),+2.30(234)\right]$.

MT-5 (5) [Cladosporin 8-O-Methylether (Asperentin 8-O-Methylether)]: Pale yellow powder, mp $236.5-237^{\circ} \mathrm{C}\left[\right.$ [lit. $^{6 b)} \mathrm{mp} 225$ and $235^{\circ} \mathrm{C}$ (double $\mathrm{mp})],[\alpha]_{\mathrm{D}}^{19}+71^{\circ}\left(c=0.33, \mathrm{CHCl}_{3}\right)\left[{ }^{1 \mathrm{it} .}{ }^{6 b)}[\alpha]_{\mathrm{D}}^{20}+72^{\circ}\left(c=0.1, \mathrm{CHCl}_{3}\right)\right]$. EIMS $m / z$ (\%): $306\left(3, \mathrm{M}^{+}\right), 288$ (9), 208 (19), 193 (34), 165 (28), 81 (100). UV $\lambda_{\max }^{\mathrm{MeOH}} \mathrm{nm}(\log \varepsilon): 214(4.33), 226$ (sh, 4.23), $265(4.10), 298$ (3.82) [lit. $\left.{ }^{6 b)} 227(4.27), 266(4.15), 298(3.89)\right] \mathrm{CD}(1.47 \mathrm{mM}, \mathrm{MeOH}) \Delta \varepsilon(\mathrm{nm})$ : +1.34 (297), + $1.12(288),+4.18(270),-0.78(251),+4.01(233)\left[\right.$ lit. $^{6 b)}$ $+1.51(296),+4.70(269),-0.91(251),+4.39(232)]$.

MT-6 (6) [Tardioxopiperazine A (cyclo-L-Alanyl-5-isopentenyl-2- $\left(1^{\prime}, 1^{\prime}-\right.$ dimethylallyl)-L-tryptophan)]: Pale yellow amorphous, $[\alpha]_{D}^{22}-30^{\circ}(c=0.20$, $\mathrm{CHCl}_{3}$ ), EI-MS $m / z(\%): 393\left(15, \mathrm{M}^{+}\right), 267$ (100), 251 (25). HR-EI-MS $m / z$ : 393.2396 $\left(\mathrm{C}_{24} \mathrm{H}_{31} \mathrm{~N}_{3} \mathrm{O}_{2}\right.$ requires 393.2416). UV $\lambda_{\max }^{\mathrm{MeOH}} \mathrm{nm}(\log \varepsilon): 229$ (4.46), 281 (sh, 3.85), $287(3.86), 296$ (sh, 3.79). ORD $(c=0.03, \mathrm{MeOH})$ $[\phi](\mathrm{nm}):+1150^{\circ}(305),-19000^{\circ}(235),+18400^{\circ}(212)$.

MT-7 (7) [Tardioxopiperazine B (cyclo-L-Alanyl-7-isopentenyl-2- $\left(1^{\prime}, 1^{\prime}-\right.$ dimethylallyl)-L-tryptophan)]: Pale yellow amorphous, $[\alpha]_{\mathrm{D}}^{22}-16^{\circ}(c=0.20$, $\mathrm{CHCl}_{3}$ ), EI-MS $m / z(\%): 393\left(20, \mathrm{M}^{+}\right), 267$ (100), 251 (26). HR-EI-MS $m / z$ : 393.2397 $\left(\mathrm{C}_{24} \mathrm{H}_{31} \mathrm{~N}_{3} \mathrm{O}_{2}\right.$ requires 393.2416). UV $\lambda_{\max }^{\mathrm{MeOH}} \mathrm{nm}(\log \varepsilon): 226$ (4.40), 273 (sh, 3.79), 280 (3.79), 291 (sh, 3.70). ORD $(c=0.03, \mathrm{MeOH})$ $[\phi](\mathrm{nm}):+720^{\circ}(299),-28200^{\circ}(232),+27500^{\circ}(215)$.

MT-8 (8) (Asperflavin): Greenish amorphous (lit." ${ }^{9)}$ citrine prisms, mp $\left.225-230^{\circ} \mathrm{C}\right),[\alpha]_{\mathrm{D}}^{22}+89^{\circ}(c=0.20, \mathrm{MeOH})\left[\right.$ lit. $\left.^{9)}+4^{\circ}(c=0.3, \mathrm{MeOH})\right]$, EI-MS $m / z$ (\%): $288\left(23, \mathrm{M}^{+}\right), 270(14), 255$ (16). 241 (25), 230 (100). UV $\lambda_{\max }^{\mathrm{MeOH}} \mathrm{nm}(\log \varepsilon): 232$ (4.23), $270(4.56), 318$ (3.68), 332 (3.57), 389 (4.02) 
[lit.9) 230 (4.13), 269 (4.51), 317 (3.64), 335 (3.40), 392 (3.91)]. CD $(0.35 \mathrm{~mm}, \mathrm{MeOH}) \Delta \varepsilon(\mathrm{nm}):+0.06(394),-0.15(322),+0.17(280),-0.14$ (261), +0.02 (242).

Formation of 6-Acetyl MT-2 (10) Acetic anhydride (2 drops) was added to a solution of $2(1.5 \mathrm{mg})$ in pyridine (2 drops) to prepare a reaction mixture, which was allowed to stand at room temperature for $3.5 \mathrm{~h}$. After the addition of a small volume of ice-water, the reaction mixture was extracted with AcOEt. The AcOEt layer was washed with water and evaporated in vacuo to give a crude product $(1.4 \mathrm{mg})$. This product was purified by preparative thin layer chromatography [plate: silica gel $60 \mathrm{~F}_{254}$ (Merck), developing solvent: $n$-hexane-AcOEt $(1: 1)$, extraction solvent: $\mathrm{CHCl}_{3}$ ] to afford an orange amorphous powder $(0.8 \mathrm{mg})$, which was identical with rubrocristin-6acetate (10) in comparison of the ${ }^{1} \mathrm{H}-\mathrm{NMR}$ spectrum (in $\mathrm{CDCl}_{3}$ ) with the spectrum of rubrocristin-6-acetate described in the literature (see Table 1). ${ }^{5}$ )

Formation of MT-4 Dimethylether (11) A solution of 10\% trimethylsilyldiazomethane in $n$-hexane (Nacalai) $(100 \mu \mathrm{l})$ was added to a solution of 4 $(5.0 \mathrm{mg})$ in a mixture of $\mathrm{Et}_{2} \mathrm{O}(100 \mu \mathrm{l})$ and $\mathrm{MeOH}(100 \mu \mathrm{l})$ to prepare a reaction mixture, which was then stirred at room temperature for $17 \mathrm{~h}$. Evaporation of the reaction mixture in vacuo afforded MT-4 dimethylether (11) (5.3 mg), pale yellow amorphous, $[\alpha]_{\mathrm{D}}^{19}+79^{\circ}\left(c=0.10, \mathrm{CHCl}_{3}\right),{ }^{1} \mathrm{H}-\mathrm{NMR} \delta$ (ppm) from TMS in DMSO- $d_{6}: 1.08\left(3 \mathrm{H}, \mathrm{d}, J=6.3 \mathrm{~Hz}, \mathrm{CH}_{3}-15\right), 1.21(1 \mathrm{H}$, m, $\left.\underline{C H}_{a} \mathrm{H}_{b}-13\right), 1.29\left(1 \mathrm{H}, \mathrm{m}, \mathrm{C}_{\mathrm{a}} \mathrm{H}_{\mathrm{b}}-11\right), 1.62\left(5 \mathrm{H}, \mathrm{m}, \mathrm{C}_{\mathrm{a}} \mathrm{H}_{\mathrm{b}}-9, \mathrm{CH}_{\mathrm{a}} \underline{\mathrm{H}}_{\mathrm{b}}-11\right.$, $\left.\mathrm{CH}_{2}-12, \mathrm{CH}_{\mathrm{a}} \underline{\mathrm{H}}_{\mathrm{b}}-13\right), 2.03\left(1 \mathrm{H}, \mathrm{m}, \mathrm{CH}_{\mathrm{a}} \underline{\mathrm{H}}_{\mathrm{b}}-9\right), 2.88\left(2 \mathrm{H}, \mathrm{m}, \mathrm{CH}_{2}-4\right), 3.81(3 \mathrm{H}$, s, $\mathrm{CH}_{3} \mathrm{O}-8$ or -6$), 3.82(1 \mathrm{H}, \mathrm{m}, \mathrm{CH}-14), 3.84\left(3 \mathrm{H}, \mathrm{s}, \mathrm{CH}_{3} \mathrm{O}-6\right.$ or -8$), 3.94$ (1H, m, CH-10), 4.39 (1H, m, CH-3), $6.49(1 \mathrm{H}, \mathrm{d}, J=2.1 \mathrm{~Hz}, \mathrm{CH}-5), 6.54$ (1H, d, $J=2.1 \mathrm{~Hz}, \mathrm{CH}-7)$. CD (1.56 mM, MeOH) $\Delta \varepsilon(\mathrm{nm}):+1.53(297)$, +6.35 (269), $-1.64(250),+4.28(232)$.

Formation of Compound 11 from MT-5 A solution of $10 \%$ trimethylsilyldiazomethane in $n$-hexane (Nacalai) $(500 \mu$ l) was added to a solution of $5(5.0 \mathrm{mg})$ in a mixture of $\mathrm{Et}_{2} \mathrm{O}(200 \mu \mathrm{l})$ and $\mathrm{MeOH}(300 \mu \mathrm{l})$ to prepare a reaction mixture, which was then stirred at room temperature for $40 \mathrm{~min}$. Evaporation of the reaction mixture in vacuo afforded a product $(4.2 \mathrm{mg})$, pale yellow amorphous, which was identical with 11 in terms of ' $\mathrm{H}-\mathrm{NMR}$ spectrum, $[\alpha]_{\mathrm{D}}$, and $\mathrm{CD}$ spectrum.

Acknowledgements We are grateful to Prof. Y. Ebizuka of the University of Tokyo for the gift of an authentic sample of questin. This study was supported in part by a Grant-in-Aid for Scientific Research (No. 09672273) from the Ministry of Education, Science, Sports and Culture of Japan, and by a grant (No. JB-98-07) from the Cosmetology Research Foundation, Tokyo, Japan.

\section{References and Notes}

1) a) Fujimoto H., Satoh Y., Nakayama M., Takayama T., Yamazaki M., Chem. Pharm. Bull., 43, 547-552 (1995); idem, The 37th Symposium on the Chemistry of Natural Products Symposium Papers, Tokushima, 1995, pp. 625-630; b) Fujimoto H., Sumino M., Nagano J., Natori H., Okuyama E., Yamazaki M., Chem. Pharm. Bull., 47, 71-76 (1999); c) Fujimoto H., Nagano J., Yamaguchi K., Yamazaki M., ibid., 46, 423-429 (1998); d) Fujimoto H., Satoh Y., Yamazaki M., ibid., 46, 211-216 (1998).

2) This strain was deposited earlier at Research Institute for Chemobiodynamics, Chiba University (present name: Research Center for Pathogenic Fungi and Microbial Toxicoses, Chiba University). Now, the voucher specimen is also on deposit in our laboratory.

3) Mahmoodian A., Stickings C. E., Biochem. J., 92, 369-378 (1964).

4) Turner W. B., Aldridge D. C., "Fungal Metabolites II," Academic Press Inc., London, 1983, pp. 140-148.

5) Anke H., Kolthoum I., Zaehner H., Laatsch H., Arch. Microbiol., 126, 223-230 (1980).

6) a) Scott P. M., Walbeek W. V., MacLean W. M., J. Antibiotics, 24, 747-755 (1971); b) Grove J. F., J. Chem. Soc., Perkin Trans. 1, 1972, 2400-2406; c) Springer J. P., Cutler H. G., Crumley F. G., Cox R. H., Davis E. E., Thean J. E., J. Agric. Food Chem., 29, 853-855 (1981).

7) Ishikawa M., Hara S., Furuya T., Nakazawa Y., "Hakuso Kuromatogurafi," Nanzando Inc., Tokyo, 1972, pp. 95-99.

8) a) Quilico A., Panizzi L., Chem. Ber., 76, 348-358 (1943); Nakashima R., Slater G. P., Tetrahedron Lett., 1971, 2649-2650; Fujimoto H., Annual Report of Research Institute for Chemobiodynamics, Chiba University, 5, 9-43 (1977); b) Romanet R., Chemizart A., Duhoux S., David S., Bull. Soc. Chim. Fr. 1963, 1048-1056; c) Houghton E., Saxton J. E., J. Chem. Soc. (C), 1969, 1003-1012.

9) Grove J. F., J. Chem. Soc., Perkin Trans. 1, 1972, 2406-2411.

10) Huang H.-C., Chang J.-H., Tung S.-F., Wu R.-T., Foegh M. L., Chu S.H., European J. Pharmacol., 211, 359-364 (1992). 